\title{
PENGARUH MOTIVASI AWAL KULIAH MAHASISWA STKIP WIDYA YUWANA TERHADAP SEMANGAT PASTORAL DI LINGKUNGAN
}

\author{
Oleh : \\ Bonaventura Praba Caraka, Agustinus Supriyadi ${ }^{*}$ \\ STKIP Widya Yuwana \\ *) penulis korespondensi, atsywhw@widyayuwana.ac.id
}

\begin{abstract}
Motivation is a conscious effort, which comes from within and outside of a person. Motivation is affecting a person's behavior so that he moved his heart to act to do something to achieve a certain result or goal. The call to be a catechist must be well motivated and not just looking for a position. This motivation is also needed by students of STKIP Widya Yuwana, as a potential catechist. The issues that arise are: whether the students of STKIP Widya Yuwana have pure motivation from inside themself as catechist? Are their motivations fixed or changed? Do they have the motivation to serve? How far the initial motivation to enter college to give influence for students of STKIP Widya Yuwana? How does motivation have an impact on pastoral care, which is the duty and responsibility of students of STKIP Widya Yuwana, as a potential catechist?Based on the problem, the purpose of this research is to see how far the influence of early motivation for college students of STKIP Widya Yuwana to the spirit of service in the environment.Through questionnaires to 48 respondents using quantitative research methods, it was found that most of the students admitted that there was an influence between the initial motivation to enter the lecture toward the pastoral practice in the environment, but the initial motivation of the students as candidates for catechism and/religious teachers needs to be refined so that students seriously answer the call of his life as a catechist candidate, not just to pursue offers that offer a position or salary alone. Thus, the coaching of these students needs to get the attention of many parties.
\end{abstract}

Keywords: Early Motivation, Motive, Pastoral, Environmental Pastoral Practice 


\section{PENDAHULUAN}

Setiap manusia memiliki cita-cita, harapan maupun tujuan yang ingin dicapai dalam hidupnya. Mereka berusaha meraih cita-cita dan memenuhi harapan serta mencapai tujuan tersebut karena didasari adanya kebutuhan dalam kehidupannya. Tindakan manusia untuk memenuhi kebutuhan-kebutuhan dalam hidupnya memerlukan adanya daya dorong, baik dorongan dari dalam maupun dari luar. Daya dorong tersebut disebut sebagai motif. Motif merupakan dorongan yang sudah terikat pada suatu tujuan. Motif manusia merupakan dorongan, keinginan, hasrat dan tenaga penggerak lainnya yang berasal dari dalam diri manusia, untuk melakukan sesuatu (Ahmadi, 1991: 196).

Motif yang ada dalam tindakan seseorang dapat membantu dan mengarahkan seseorang untuk mencapai apa yang diinginkannya. Tindakan manusia untuk memenuhi kebutuhan hidupnya tersebut selalu mengarah pada suatu tujuan. Handoko dalam bukunya "Motivasi Daya Penggerak Tingkah Laku" (Handoko, 1992: 19) menjelaskan hubungan antara kebutuhan, tingkah laku dan tujuan bukan hanya sebagai lingkaran motivasi (motivation circle), melainkan sebagai siklus motivasi (motivational cycle).Bila kebutuhan yang pertama sudah terpenuhi, akan terjadi keadaan tidak seimbang pada taraf yang lebih tinggi; keadaan ini menimbulkan kebutuhan baru dan seterusnya, sehingga manusia boleh dikatakan tidak pernah diam.

Sebagai suatu alasan/dorongan yang menyebabkan individu berbuat sesuatu/melakukan tindakan tertentu, motif membutuhkan tenaga atau faktor yang terdapat dalam diri manusia, yang mengarahkan dan mengorganisir tingkah laku, yang disebut dengan motivasi. Adanya motivasi internal dan pertama dalam setiap individu sangat dominan untuk memenuhi kebutuhan dan mencapai tujuannya. Meskipun demikian, motivasi eksternal juga dapat memberikan pengaruh yang besar. Stimulus/rangsangan dari luar individu seringkali lebih dapat mendorong seorang individu untuk beralih kepada rangsangan tersebut, misalnya seorang individu ingin bekerja karena ditawari gaji yang tinggi. Kenyataan ini dialami juga oleh kaum muda dalam kehidupannya sehari-hari. Mereka dihadapkan pada realita di mana kaum muda memiliki cita-cita dari dalam dirinya sendiri, tetapi di sisi lain banyak rangsangan dari luar yang lebih kuat mendorong kaum muda untuk beralih pada motivasi dari luar dirinya.

Mahasiswa STKIP Widya Yuwana, sebagai kaum muda, juga memiliki motivasi pertama dalam dirinya ketika memutuskan untuk masuk kuliah. Sebagai kaum muda yang memiliki cita-cita, mereka juga berhadapan dengan persoalanpersoalan dalam hidupnya. Mereka mengalami konflik antara motivasi pertama masuk kuliah dengan kenyataannya, sebab apa yang mereka hadapi tidak selalu sesuai dengan harapannya. Ada beberapa motivasi yang muncul pada umumnya antara lain adalah: sebagai Pegawai Negeri Sipil (PNS), guru agama di sekolah, 
dan tawaran-tawaran lain yang muncul, atau bahkan tawaran menyangkut gaji yang lebih besar. Beberapa motivasi tersebut tidak sesuai dengan panggilan sebagai katekis. Konflik tersebut seringkali berakibat pada tindakan/tingkah laku yang tampak dalam kehidupan sehari-hari, terutama dalam menjalankan tugas dan tanggung jawabnya sebagai seorang mahasiswa (calon katekis).

Dari pemaparan di atas ada beberapa pertanyaan reflektif yang perlu diajukan antara lain adalah: Apakah mahasiswa STKIP Widya Yuwana memiliki motivasi murni dari dalam dirinya sebagai katekis? Apakah motivasi mereka tetap atau berubah? Apakah mereka memiliki motivasi untuk melayani? Sejauhmana motivasi awal masuk kuliah memberikan pengaruh bagi mahasiswa STKIP Widya Yuwana? Bagaimana motivasi berdampak pada pelayanan pastoral, yang menjadi tugas dan tanggung jawab mahasiswa STKIP Widya Yuwana, sebagai calon katekis? Dan masih banyak lagi pertanyaan senada yang mungkin dapat dimunculkan. Penelitian ini hendak menemukan jawaban atas berbagai persoalan dan pertanyaan yang muncul tersebut, agar nantinya mahasiswa STKIP Widya Yuwana semakin menyadari motivasi awal kuliahnya sebagai sebuah dorongan untuk melaksanakan tugas dan tanggung jawabnya sebagai seorang calon katekis.

\section{MOTIVASI AWAL KULIAH DAN PASTORAL LINGKUNGAN \\ 2.1 Hakikat Motivasi}

Motivasi merupakan unsur penting dalam tindakan manusia untuk memenuhi kebutuhan serta mencapai tujuan dalam hidupnya. Motivasi juga dapat diartikan sebagai kekuatan yang muncul dari dalam ataupun dari luar diri manusia dan membangkitkan semangat serta ketekunan untuk mencapai sesuatu yang diinginkan.

Dalam konteks ini, motivasi dimengerti sebagai suatu daya pendorong yang mempengaruhi manusia untuk memberikan arah supaya apa yang menjadi tujuannya dapat tercapai. Motivasi mencakup di dalamnya arah atau tujuan tingkah laku, kekuatan respons dan kegigihan tingkah laku. Istilah motivasi juga mencakup sejumlah konsep seperti dorongan (drive), kebutuhan (need), rangsangan (incentive), ganjaran (reward), penguatan (reinforcement), ketetapan tujuan (goal setting), harapan (expectancy), dan sebagaianya. Selain konsepkonsep tersebut, Good dan Brophy yang dikutip Hamzah (2016: 7) mengungkapkan bahwa di dalam motivasi juga mengandung konsep-konsep,

seperti kebutuhan untuk berprestasi, kebutuhan berafiliasi, kebiasaan dan keingintahuan seseorang terhadap sesuatu. Ngalim (1995: 62) juga menambahkan bahwa definisi motivasi mengandung tiga komponen pokok, yaitu menggerakkan, mengarahkan, dan menopang tingkah laku. Menurut Hamzah, hakikat motivasi belajar adalah dorongan internal dan eksternal pada siswa-siswi yang sedang 
belajar untuk mengadakan perubahan tingkah laku. Hamzah melihat bahwa dalam motivasi belajar terdapat indikator atau unsur-unsur yang mendukung, antara lain: adanya hasrat dan keinginan berhasil, adanya dorongan dan kebutuhan dalam belajar, adanya harapan dan cita-cita masa depan, dan sebagainya (Hamzah, 2016: 23).Tokoh lain juga melihat adanya implikasi yang berbeda bagi teori motivasi, seperti F.W. Taylor tentang manajemen ilmiah, Teori motivasi kesehatan Herzberg, dan lain-lain.

Mencermati beberapa pendapat tersebut dapatlah dikatakan bahwa setiap definisi dari motivasi, yang diungkapkan oleh para ahli, memberikan penekanan yang berbeda-beda. Penekanan tersebut diberikan berdasarkan pada ide dan pengamatan tentang tingkah laku/tindakan, kebutuhan serta tujuan dari kehidupan manusia sendiri (Hamzah, 2016: 46). Maslow memiliki penekanan tersendiri dalam teori motivasinya, meskipun teori motivasi manusia dapat diterapkan pada hampir seluruh aspek kehidupan pribadi serta kehidupan sosial. Dalam bukunya “Motivasi dan Kepribadian”, Maslow menjelaskan dengan gamblang tentang teori motivasi manusia yang sampai sekarang dikenal dengan teori kebutuhan. Penjelasan mengenai konsep motivasi manusia menurut Maslow mengacu pada lima kebutuhan pokok yang disusun secara hirarkis. Hirarki tersebut disusun berdasarkan pada anggapan bahwa ketika seseorang telah terpuaskan oleh satu tingkat kebutuhan tertentu, ia akan bergeser ke tingkat yang lebih tinggi. Menurut teori tentang kebutuhan dasar, manusia dimotivasikan oleh sejumlah kebutuhan dasar yang bersifat sama untuk seluruh spesies, tidak berubah dan berasal dari sumber genetis atau naluriah. Kebutuhan-kebutuhan itu juga bersifat psikologis, bukan semata-mata fisiologis (Frank, 1987: 70).

Kebutuhan-kebutuhan dasar (basic need) yang dimaksudkan Maslow adalah kebutuhan fisiologi, kebutuhan akan rasa aman, kebutuhan akan cinta kasih dan kebutuan sosial, kebutuhan akan penghargaan, dan sebagainya. Kebutuhankebutuhan dasar tersebut memilikiketerkaitan saling satu sama lain, karena kebutuhan manusia yang tidak pernah terpuaskan (Maslow, 1984: 43-57).

\subsection{Pengertian Pastoral}

Gereja merupakan wujud nyata kehadiran Kerajaan Allah di dunia. Kristus telah mewariskan tugas perutusan-Nya kepada para Rasul dan penggantinya, untuk mewartakan kabar gembira dan keselamatan bagi semua orang. Maka, Gereja ada karena mendapat tugas perutusan dari Kristus sendiri. Tugas perutusan dari Kristus tersebut memiliki dimensi kemuridan. Kristus sendiri bersabda: "Pergilah, jadikanlah semua bangsa murid-Ku” (Mat 28:19). Gambaran tentang kemuridan ini dikatakan dalam Injil Yohanes. Tanda kemuridan merupakan panggilan kasih, "Kamu adalah murid-murid-Ku, yaitu jikalau kamu saling 
mengasihi” (Yoh 13: 35), yang semuanya itu berpangkal pada kesatuan erat dengan Bapa (Cahyadi, 2009: 21).

Tindakan kemuridan ini memuat aspek relasi dan perutusan. Ada sebuah relasi dengan Allah yang berpangkal pada kasih, karena Allah sendiri adalah kasih. Kasih Allah yang nyata itu tampak dalam tugas Kristus yang mewahyukan Bapa kepada manusia. Persatuan kita dengan Kristus sebagai putera Bapa sekaligus memberi kita tugas untuk menguraikan sifat hakiki yang ada pada Allah, yaitu kasih. Kasih kepada Allah harus dinyatakan dalam cinta kepada sesama, terutama kepada sesama yang paling mendambakan kasih itu, ialah kaum miskin: yang lapar, yang haus, yang dipengasingan, yang telanjang, yang sakit dan yang ada dalam penjara (bdk. Mat 25: 31-46). Oleh sebab itu, relasi kasih itu hendaklah dinyatakan melalui kesaksian hidup, dan itulah yang menjadi perutusan Gereja: mewujudkan, menghadirkan dan mengalirkan kasih (Bross, 1970: 6).

Kesaksian yang mewujudkan, menghadirkan dan mengalirkan kasih itu dilaksanakan melalui tindakan penggembalaan. Penggembalaan Gereja terutama diletakkan dalam kepemimpinan serta pelayanan pastor. Maka, istilah pastoral pertama-tama muncul dalam kaitannya dengan tugas pastor. Istilah pastoral berasal dari kata pastor, yang dalam bahasa Latin berarti gembala. Kata "gembala” seringkali dipakai untuk menunjuk kepada Tuhan sebagai gembala bagi Israel, umat-Nya dalam Perjanjian Lama, sebagaimana diungkapkan dalam Mazmur 23, “Tuhan adalah Gembalaku, aku tak akan kekurangan suatu apapun”. Sifat penggembalaan Allah ini juga ditampilkan dalam Perjanjian Baru, yaitu Allah yang mengarahkan, menuntun, mendampingi, melindungi, merawat, menyembuhkan, menyertai, menyediakan yang terbaik bagi kehidupan umat-Nya, mencari yang hilang, melayani, melibatkan, memberdayakan, mengampuni dan menyatukan (bdk. Luk 15: 1-32; Yoh 10: 10b-18; 17: 21). Oleh karena itu, pengertian pastoral dikembalikan pada sifat penggembalaan Allah yang menghendaki keselamatan manusia (Mardikartono, 2016: 1-2).

Pastoral adalah sifat penggembalaan. Pengistilahan ini dikaitkan dengan diri Yesus sendiri dan karya-karya-Nya sebagai "Pastor Sejati” atau "Gembala yang Baik” (Yoh 10). Ungkapan ini mengacu pada pelayanan Yesus yang tanpa pamrih, bersedia memberikan pertolongan dan pengasuhan terhadap para pengikut-Nya, bahkan rela mengorbankan nyawa-Nya. Van Beek (2003: 10) memberikan penegasan bahwa istilah pastor dalam konotasinya berarti merawat atau memelihara. Sikap pastoral harus mewarnai setiap sendi pelayanan setiap orang sebagai orang-orang yang sudah dirawat dan diasuh oleh Allah dengan sungguh-sungguh. Berpastoral juga dapat berarti karya penggembalaan yang mengandung 2 unsur sekaligus, yakni unsur ilahi dan insani. Ilahi karena karya pastoral menyangkut urusan rohani tetapi juga insani karena pastoral berurusan juga dengan kehidupan konkrit manusia (duniawi). 
Berdasarkan uraian di atas, pastoral adalah sifat penggembalaan Allah dan diri Yesus Gembala yang baik, yang mengasihi umat-Nya. Pastoral tidak hanya dilakukan oleh pastor, melainkan menjadi tugas dan tanggung jawab semua orang beriman kristiani, yang dipersatukan oleh pembaptisan. Paus Paulus VI dalam ensikliknya Evangelii Nuntiandi yang dikutip oleh Cahyadi (2009: 45) menegaskan bahwa tugas perutusan Gereja adalah tugas perutusan yang melibatkan semua umat beriman, dalam berbagai bentuk dan wujudnya, berkat pembaptisan serta berkat daya kekuatan Roh Kudus lewat krisma, agar karya keselamatan Allah dapat semakin terwujud dan tersebar.

Dasar dari tugas penggembalaan juga dinyatakan dalam surat Rasul Petrus, “Gembalakanlah kawanan domba Allah yang ada padamu, jangan dengan paksa, tetapi dengan sukarela sesuai dengan kehendak Allah, dan jangan karena mau mencari keuntungan, tetapi dengan pengabdian diri. Janganlah kamu berbuat seolah-olah kamu mau memerintah atas mereka yang dipercayakan kepadamu, tetapi hendaklah kamu menjadi teladan bagi kawanan domba itu (1Ptr 5:2-3).” Setelah Konsili Vatikan II, kata pastoral pertama-tama dikaitkan dengan penggembalaan Allah dalam umat dan di tengah masyarakat. Berpastoral dipahami sebagai sifat penghayatan iman bahwa Allah adalah Gembala kita (Mardikartono, 2016: 3). Pastoral meliputi seluruh bidang kehidupan dan bukan hanya terjadi di paroki serta hanya dilaksanakan oleh pastor paroki.

Salah satu bentuk pelayanan Gereja adalah pelayanan pastoral. Pelayanan ini dilaksanakan Gereja dalam dan melalui diri para petugas pastoral, baik petugas pastoral tertahbis maupun petugas pastoral non tertahbis. Keduanya memiliki dasar pelayanan yang berbeda, namun keduanya berpartisipasi dalam satu imamat Kristus dalam cara yang berbeda serta memiliki tujuan pelayanan yang sama.Dalam reksa pastoral paroki secara yuridis memang kewenangan dimiliki oleh Pastor sebagai representasi Uskup di wilayah itu. Sehingga muncul pandangan bahwa karya pastoral hanya milik pastor. Pemikiran semacam itu hendaknya ditinggalkan karena di dalam ajaran dan aturan Gereja telah terjadi perubahan makna tentang karya pastoral. Meskipun demikian tidaklah dipungkiri bahwa kenyataan masih ada pastor yang berperan sentral mengatur semua karya pastoral tanpa melibatkan kaum awam.

Kitab Hukum Kanonik (KHK, 1983) menyebutkan bahwa umat beriman berkat sakramen pembaptisan ikut ambil bagian di dalam tugas kepemimpinan umat beriman (bdk. Kan 204). Meskipun di dalam Gereja Katolik kuasa kepemimpinan diberikan kepada orang yang tertahbis, tapi dalam pelaksanaan kuasa tersebut, orang beriman kristiani awam dapat dilibatkan dalam kerjasama menurut norma hukum (bdk. Kan 129). Jadi, kaum awam beriman sebagai umat Allah memiliki kewajiban untuk terlibat aktif dalam karya pastoral Gereja. Secara singkat, berpastoral adalah keikutsertaan manusia dalam karya Allah, yang 
menggembalakan, menyelenggarakan hidup, dan menyelamatkan manusia. Tujuan berpastoral adalah agar manusia mengalami penggembalaan Allah yang menyelamatkan (Mardikartono, 2016: 4).

\subsection{Pastoral di Lingkungan}

Pastoral merupakan karya penggembalaan yang menjadi tugas dan tanggung jawab seluruh umat beriman kristiani, yang telah dipersatukan melalui pembaptisan. Karya-karya penggembalaan ini menyangkut banyak aspek dan mengarahkan perspektif penggembalaan kepada semua kegiatan dan fungsi Gereja. Karya penggembalaan bagi lingkungan haruslah berpijak pada pengalaman Jemaat perdana, lingkungan dikembangkan menjadi suatu cara berada dan cara hidup umat di tingkat basis. Cara hidup itu ditandai dengan semangat, kegiatan, dan gerakan tertentu (Sugiyana, 2013: 67).

Lingkungan ada karena ada Paroki. Tidak ada lingkungan yang mandiri lepas dari paroki. Semua lingkungan terikat dan berada di bawah reksa pastoral paroki. Sebaliknya, juga tidak ada paroki teritorial yang tanpa lingkungan. hubungan antara paroki dan lingkungan bukanlah hubungan yang pasif tetap hubungan yang aktif dan dinamis, yang masing-masing memiliki hak dan kewajiban yang timbal balik. Lingkungan menjadi pusat pastoral/fokus pastoral, yang berarti lingkungan menjadi arah, tujuan, prioritas atau perhatian seluruh gerak pelayanan dan penggembalaan (Sugiyana, 2013: 14).Tindakan penggembalaan di lingkungan dimaksudkan supaya umat kristiani menghayati imannya setiap hari dalam aneka kegiatan, antara lain: misa dan sembahyangan lingkungan, sekolah Minggu, paguyuban mudika, pendalaman Kitab Suci, dan sebagainya. Melalui kegiatan-kegiatan itu semua, pembinaan iman umat dijalankan (Gitowiratmo, 2003: 105).

Berdasarkan pengertian pastoral dan lingkungan di atas, pastoral di lingkungan dapat dimengerti sebagai tindakan penggembalaan yang dilaksanakan dalam lingkup lingkungan, sebagai bagian terkecil dari paroki dan di bawah reksa pastoral paroki. Reksa pastoral paroki bagi lingkungan menjadi tanggung jawab pengurus lingkungan dan pengurus yang lain, sebagai sebagai bagian integral dari paroki.Praktik pelayanan pastoral di lingkungan merupakan salah satu program matakuliah yang ada di STKIP Widya Yuwana Madiun. Program ini menyangkut praktikum mingguan, praktikum pendampingan anak-anak, refleksi pastoral harian, mingguan, paskah, natal, kerja tim dan praktikum kunjungan (UPTP STKIP Widya Yuwana, 2017: 38).

Menurut buku pedoman program pastoral (2017: 13), diadakannya Praktik Pastoral Lapangan (PPL) ini bertujuan agar mahasiswa memiliki kemampuan dasar melaksanakan kegiatan-kegiatan yang menjadi kualifikasi seorang katekis akademis. Katekis akademis adalah orang-orang yang secara khusus mengikuti 
pendidikan katekis supaya memiliki peningkatan kualitas hidup pribadi dari sisi visi dan wawasan hidup menggereja, motivasi dan spiritualitas, pengetahuan biblis-teologis dan iman, serta peningkatan kualitas pelayanan katekis. Pelayanan katekis yang dimaksudkan dalam pedoman pastoral tersebut adalah pastoral keteketis yang berorientasi pada program yang visioner, salah satunya adalah berdasarkan atas arah dasar keuskupan Surabaya.

Pelayanan pastoral tidak hanya mengandalkan kualifikasi katekis, tetapi juga harus memperhatikan sistematika pelayanan pastoral yang dapat diukur dengan parameter-parameter yang dapat dipertanggungjawabkan secara keilmuan, maupun kebenaran ajaran Gereja, serta memberi kontribusi terhadap perubahan, yang berbentuk perubahan paradigma berpikir sampai perubahan sosial yang dijiwai oleh nilai-nilai Injil/Kerajaan Allah. Melalui konsep tersebut, katekis atau pewarta diajak untuk menyadari bahwa karya pewartaan merupakan karya Gereja sehingga karya tersebut bukan merupakan karya pribadi, namun ditempatkan dalam rangka karya pewartaan Gereja secara keseluruhhan (Komkat KAS, 2007: 60).

Berdasarkan pemahaman di atas, pihak STKIP Widya Yuwana melalui buku pedoman pastoral memberikan rincian berkaitan dengan PPL Lingkungan dalam pasal-pasal. Pasal-pasal tersebut memuat segala hal yang berkaitan dengan tanggung jawab mahasiswa selama melaksanakan praktik pelayanan pastoral di lingkungan, antara lain: kegiatan praktikum yang wajib dilaksanakan, jenis-jenis praktikum (regular dan non regular), target praktikum pembinaan mental dan kepribadian mahasiswa, dsb (UPTP STKIP Widya Yuwana, 2017: 16-18).

\section{HASIL PENELITIAN MENGENAI PENGARUH MOTIVASI AWAL MAHASISWA TERHADAP SEMANGAT PASTORLA DI LINGKUNGAN}

Penelitian ini menggunakan metode deskriptif korelasi dengan menggunakan pendekatan kuantitatif, yakni mendeskripsikan mengenai pengaruh motivasi awal masuk kuliah bagi mahasiswa STKIP Widya Yuwana Madiun terhadap semangat pelayanan di lingkungan. Sujarweni (2014: 39) menjelaskan bahwa penelitian kuantitatif adalah jenis penelitian yang menghasilkan penemuanpenemuan yang dapat dicapai dengan menggunakan prosedur-prosedur statistik atau cara-cara lain dari kuantifikasi (pengukuran). Pendekatan kuantitatif memusatkan karakteristik tertentu di dalam kehidupan manusia yang dinamakannya sebagai variabel. Dalam pendekatan kuantitatif hakikat hubungan di antara variabel-variabel dianalisis dengan menggunakan teori yang obyektif.

Penelitian ini dilaksanakan di kampus STKIP Widya Yuwana, yang berlokasi di Jalan Soegijopranata TP. 13 Madiun. Dalam penelitian ini, peneliti mengambil sampel dari keseluruhan populasi mahasiswa STKIP Widya Yuwana, 
yaitu seluruh mahasiswa tingkat II sampai dengan tingkat IV, yang telah menyelesaikan praktik pastoral Lingkungan.

Penelitian ini dilaksanakan melalui 4 tahap yaitu yang dimulai dari persiapan, pelaksanaan, proses analisa dan interpretasi data, dan verifikasi data. Tahap persiapan merupakan langkah awal pada sebuah penelitian sebelum dilakukan pengambilan data. Pada tahap persiapan, yang dilakukan peneliti adalahmenyusun rancangan dan pertanyaan-pertanyaan untuk penelitian. Kedua, peneliti memilih lapangan penelitian yang merupakan sasaran untuk melakukan penelitian. Ketiga, sebelum peneliti mengadakan penelitian, terlebih dahulu mengurus surat-surat perizinan. Kemudian tahap pelaksanaan merupakan inti dari sebuah penelitian. Adapun hal-hal yang dilakukan dalam tahap pelaksanaan penelitian yakni memahami latar belakang penelitian, memasuki lapangan penelitian, berperan serta sambil melakukan proses pengambilan data lapangan melalui wawancara. Tahap analisa dan interpretasi data, proses analisis data dimulai dengan menelaah seluruh data yang sudah diperoleh melalui hasil wawancara dengan responden. Kemudian peneliti melakukan reduksi data yang dilakukan dengan jalan membuat abstraksi. Abstraksi tidak lain daripada usaha membuat rangkuman atas data yang dikumpulkan secara sistematis dan terstruktur. Hasil rangkuman data itu kemudian disusun dalam satu kesatuan yang logis dan berkaitan satu dengan yang lain. Proses verifikasi data merupakan upaya untuk melakukan check dan recheck atas data yang dikumpulkan, hasil analisa data yang dilakukan dengan kesimpulan yang dibuat. Bila terdapat data atau informasi yang meragukan atau membingungkan maka informasi itu akan dicek, diolah dan diklarifikasi hingga mendapatkan kebenaran yang sesungguhnya.

Dalam penelitian ini, peneliti menggunakan statistik deskriptif untuk membuat analisis data. Statistik deskriptif adalah statistik yang digunakan untuk menganalisis data dengan cara mendeskripsikan atau menggambarkan data yang telah terkumpul sebagaimana adanya tanpa bermaksud membuat kesimpulan yang berlaku untuk umum atau generalisasi. Data-data tersebut dapat ditampilkan dalam bentuk tabel, diagram, dsb (Arikunto, 1993: 363).

Penulis menggunakan program SPSS dalam melakukan analisis data dalam penelitian ini. Setelah data terkumpul, kemudian peneliti mengolah data, menganalisa dan menyajikan hasil pengolahan data tersebut dalam bentuk tabeltabel. Hasil pengolahan data dalam tabel tersebut kemudian dideskripsikan atau diinterpretasi. Jumlah responden penelitian mahasiswa tingkat II dan tingkat IV berjumlah 48 responden.

Hasil analisa dan statistik mengenai pernyataan: "Motivasi awal saya adalah menjadi seorang calon pewarta dan/atau guru agama”, menunjukkan bahwa responden yang tidak setuju dengan pernyataan ini ada 7 (14,6\%) orang, responden yang kurang setuju ada 8 (16,7\%) orang, responden yang setuju ada 23 
(47,9\%) orang, dan responden yang sangat setuju dengan pernyataan ini ada 10 (20,8\%) orang. Berdasarkan hasil tersebut, sebagian besar responden mengaku memiliki motivasi sebagai seorang calon pewarta dan/atau guru agama. Sedangkan berdasarkan asal munculnya motivasi ditemukan bahwa responden yang mengaku tidak setuju dengan motivasi awal kuliah berasal dari diri sendiri ada $7(14,6 \%)$ orang, responden yang mengaku kurang setuju dengan motivasi awal kuliah berasal dari diri sendiri ada 13 (27,1\%) orang, responden yang mengaku setuju dengan motivasi awal kuliah meuncul dari diri sendiri ada 17 $(35,4 \%)$ orang, dan responden yang mengaku sangat setuju dengan motivasi awal masuk kuliah berasal dari diri sendiri ada 11 (22,9\%) orang. Data statistik tersebut menunjukkan bahwa sebagian besar responden mengaku motivasi awal kuliah berasal dari diri sendiri, yaitu sebanyak 17 (35,4\%) orang dan 11 (22,9\%) orang. Hasil ini sekaligus menunjukkan bahwa hakikat motivasi adalah dorongan internal dan eksternal pada diri sesorang untuk mengadakan perubahan tingkah laku. Hamzah melihat bahwa dalam motivasi belajar terdapat indikator atau unsur-unsur yang mendukung, antara lain: adanya hasrat dan keinginan berhasil, adanya dorongan dan kebutuhan dalam belajar, adanya harapan dan cita-cita masa depan, dan sebagainya (Hamzah, 2016: 23).

Selain daripada motivasi awal responden adalah untuk menjadi katekis atau guru agama, data hasil analisa dan statistik mengenai pernyataan: "Motivasi awal kuliah saya untuk menjadi PNS”, menunjukkan bahwa responden yang tidak setuju dengan pernyataan ini ada 11 (22,9\%) orang, responden yang kurang setuju ada 11 (22,9\%) orang, responden yang setuju dengan pernyataan ini ada 21 $(43,8 \%)$ orang dan responden yang sangat setuju dengan pernyataan ini ada 5 $(10,4 \%)$ orang. Ada beberapa motivasi yang muncul pada umumnya antara lain adalah: sebagai Pegawai Negeri Sipil (PNS), guru agama di sekolah, dan tawarantawaran lain yang muncul, atau bahkan tawaran menyangkut gaji yang lebih besar. Berdasarkan hasil analisa di atas ada 21 (43\%) orang dan 5 (10,4\%) orang memiliki motivasi kuliah untuk menjadi Pegawai Negeri Sipil (PNS). Hasil ini menunjukkan bahwa sebagian besar responden memiliki motivasi kuliah di STKIP Widya Yuwana adalah untuk mengejar profesi sebagai seorang PNS, selain untuk menjadi katekis dan/guru agama. Jumlah ini sesuai dengan jumlah responden yang motivasinya muncul dari dalam diri responden sendiri (tabel 14), yaitu sebanyak 17 (35,4\%) orang dan 11 (22,9\%) orang. Akan tetapi, hasil ini kurang sesuai dengan motivasi responden yang ditunjukkan pada tabel 13 bahwa ada 23 (47,9\%) orang dan 10 (20,8\%) orang mengaku memiliki motivasi untuk menjadi calon pewarta dan/atau guru agama. Meskipun demikian, hasil ini menunjukkan bahwa ada motivasi yang juga menggerakkan responden untuk mengejar kebutuhan hidup yang paling dasar, paling kuat dan paling jelas dari antara sekalian kebutuhan kebutuhan hidupnya, yaitu kebutuhan fisik. Profesi 
sebagai seorang PNS jelas memotivasi responden untuk memperoleh jaminan bagi pemenuhan kebutuhan fisiologis. Kebutuhan fisiologis adalah kebutuhan yang paling dasar, paling kuat dan mendesak pemenuhannya karena berkaitan langsung dengan kelangsungan hidup manusia. Kebutuhan ini merupakan kebutuhan dasar, yang menyangkut fungsi-fungsi biologis dasar manusia, seperti pangan, sandang, kesehatan fisik, kebutuhan seks, dan sebagainya (Frank, 1987: 71).

Hasil analisa dan statistik mengenai pengaruh motivasi awal kuliah terhadap kewajiban dan tugas praktik di lingkunganmenunjukkan bahwa responden yang tidak setuju dengan pernyataan ini ada 4 (8,3\%) orang, responden yang kurang setuju ada 8 (16,7\%) orang, responden yang setuju dengan pernyataan ini ada 26 (54,2\%) orang dan responden yang sangat setuju dengan pernyataan ini ada 10 (20,8\%) orang. Sebagian besar responden, yaitu 26 (54,2\%) orang dan 10 (20,8\%) orang, mengaku bahwa motivasi awal memiliki pengaruh terhadap pelaksanaan tugas dan kewajiban selama melaksanakan praktik pastoral di lingkungan. Hasil statistik ini sesuai dengan teori yang menyatakan bahwa perhatian seseorang banyak bergantung dari faktor stimulus. Misalnya, ketika seorang anak sedang belajar untuk memperoleh nilai yang baik atau agar lulus ujian, segala sesuatu ia curahkan pada buku atau materi yang sedang dipelajarinya. Ia sedapat mungkin mengabaikan hal-hal di sekelilingnya, yang sekiranya tidak mendukung proses belajarnya, dan tetap memusatkan perhatiannya pada buku pelajarannya agar tujuannya (memperoleh nilai yang baik/lulus ujian) dapat tercapai (Handoko, 1992: 43-49).

Hasil analisa dan statistik mengenai pernyataan: "Saya menjalankan praktik di lingkungan semata-mata untuk memenuhi kewajiban”, menunjukkan bahwa responden yang tidak setuju dengan pernyataan tersebut ada 6 (12,5\%) orang, responden yang kurang setuju dengan pernyataan tersebut ada 26 (54,2\%) orang, responden yang setuju dengan pernyataan tersebut ada $14(29,2 \%)$ orang dan responden yang sangat setuju dengan pernyataan tersebut ada 2 (4,2\%) orang. Berdasarkan data statistik tersebut sebagian besar, yaitu sebanyak $6(12,5 \%)$ orang dan 26 (54,2\%) orang responden menjawab bahwa mereka menjalankan praktik di lingkungan bukan semata-mata untuk menjalankan kewajiban. Dari data statistik tersebut menunjukkan bahwa bilamana motivasi awalnya berasal dari diri sendiri, maka tugas dan tanggung jawab yang dijalankannya tidak dilihat sebagai kewajiban semata. Hasil ini mengindikasikan bahwa sebagian besar responden dapat dikatakan mereka melaksanakan praktik di lingkungan didasarkan atas tujuan-tujuan dan kebutuhan-kebutuhan tertentu. 


\section{PENUTUP}

Hasil penelitian kuantitatif menunjukkan bahwa secara umum responden cukup memahami tentang pengertian motivasi. Hal ini terlihat dari kejelasan jawaban responden berkaitan dengan pengertian motif dan motivasi, hubungan antara motif dan motivasi, munculnya motivasi serta pengaruh motivasi terhadap kebutuhan dan untuk mencapai tujuan tertentu. Sebagian besar responden memahami motif dan motivasi sebagai daya dorong yang berasal dari dalam diri maupun dari luar diri seseorang. Selain itu, motivasi juga dianggap sebagai daya dorong yang mempengaruhi seseorang untuk memenuhi kebutuhannya dan mencapai tujuannya.

Hasil penelitian kuantitatif menunjukkan bahwa setiap responden memiliki motivasi awal masuk kuliah yang beranekaragam. Sebagian responden memiliki motivasi awal kuliah murni untuk menjadi katekis dan/guru agama. Namun, di sisi yang lain sebagian responden memiliki motivasi untuk menjadi Pegawai Negeri Sipil (PNS). Meskipun demikian, didasarkan atas motivasi-motivasi tersebut, sebagian besar responden mengaku bahwa motivasi awal masuk kuliah mereka berpengaruh terhadap kewajiban dan tugas-tugasnya salama menjalankan praktik pastoral di lingkungan.

Motivasi awal kuliah responden dapat muncul dari dalam diri sendiri maupun dari luar dirinya. Banyak responden yang mengaku motivasi awal masuk kuliah berasal dari diri sendiri, dan ada pula yang mengaku motivasinya berasal dari luar dirinya sendiri (faktor eksternal).Dari antara motivasi tersebut, baik yang dari dalam maupun dari luar diri responden, sebagian besar responden memiliki motivasi murni untuk menjadi katekis dan/guru agama, disamping motivasi lain responden yang mengaku motivasi awal kuliah adalah untuk menjadi Pegawai Negeri Sipil (PNS). Namun, dari mana munculnya motivasi tersebut dan apapun motivasi yang mendasari responden tersebut untuk masuk kuliah di STKIP Widya Yuwana, kesemuanya itu diakui memiliki pengaruh terhadap pelaksanaan praktik pastoral di lingkungan. 


\section{DAFTAR PUSTAKA}

. 1999. Alkitab Deuterokanonika. Jakarta: LAI.

2017. Buku Pedoman Akademik Prodi Ilmu Pendidikan Teologi. Madiun: STKIP Widya Yuwana.

. 1993. Dokumen Konsili Vatikan II. Jakarta: Obor.

1995. Katekismus Gereja Katolik Indonesia. Herman Yosef Embiru (Pen.).

Ende: Flores.

Abu, H.Ahmadi, dkk. 1991. Psikologi Sosial (Edisi Revisi). Jakarta: PT. Rineka Cipta.

Cahyadi, Krispurwana. 2009. Pastoral Gereja. Yogyakarta: Kanisius.

Frank, G. Goble. 1987. Psikologi Humanistik Abraham Maslow. Yogyakarta: Kanisius.

Go, P. 1989. Dinamika Pengembangan Paroki. Malang: Dioma.

Hamzah, B. Uno. 2016. Teori Motivasi dan Pengukurannya. Jakarta: Bumi Aksara.

Handoko,Martin. 1992. Motivasi Daya Penggerak Tingkah Laku. Yogyakarta: Kanisius.

Janssen, P. 1983. Dasar-dasar Pastoral Umat. Malang: Institut Pastoral Indonesia.

KWI. 2006. Kitab Hukum Kanonik. Bogor: Percetakan Grafika Mardi Yuana.

Mardikartono, J. B. 2016. Pelayanan Pastoral Berbasis Data. Yogyakarta: Kanisius.

Maslow.H., Abraham. 1984. Motivasi dan Kepribadian. Nurul Iman (Pen.). Jakarta : Pustaka Binaman Pressindo.

Nouwen, J. M. Henri. 1986. Pelayanan yang Kreatif. Yogyakarta: Kanisius.

Purwanto, M. Ngalim. 1995. Psikologi Pendidikan. Bandung: PT. Remaja Rosdakarya.

Robbins, Stephen P. \& Timothy A. Judge. 2013. Organizational Behavior $\left(15^{\text {th }}\right.$ edition). USA: Pearson International Edition, Prentice Hall.

Sudarma, R. 2011. Menggapai Pribadi Lebih Bermakna. Yogyakarta: Razan Media Press.

Sugiyana, Fx. 2013. Lingkungan. Yogyakarta: Kanisius.

Sujarweni, V. Wiratna. 2014. Metodologi Penelitian. Yogyakarta: Pustaka Baru Press.

Tim Edukasi Misi Muntilan Pusat Animasi Misioner. 2007. Paguyuban Lingkungan. Yogyakarta.

UPTP STKIP Widya Yuwana. 2017. PedomanProgram Pastoral Tahun 2017. Madiun. 